\title{
A closer look into down syndrome: Unlocking the mystery of alzheimer's disease
}

\author{
Nakisa Malakooti* \\ Department of Biochemistry and Molecular Biology, Monash University, Clayton, Victoria, Australia
}

\begin{abstract}
Down syndrome and Alzheimer's disease share the same neuropathological hallmarks. Down syndrome individuals have an extra whole or part of chromosome 21. Exploring the molecular and cellular events governed by the genes on chromosome 21 gives the opportunity to find avenues for prevention or cure of Alzheimer's disease in both Down syndrome and the general population.
\end{abstract}

\section{Introduction}

Alzheimer's disease (AD), the most common type of dementia, was first defined by Alois Alzheimer, a German psychiatrist, and neuropathologist in 1906 [1]. The worldwide prevalence of dementia is fifty million, and this number is expected to reach 75 million in 2030 if no cure is found [2]. Furthermore, it is the second leading cause of death in Australia [3]. To date, the challenge of finding a cure for Alzheimer's disease continues a century after its discovery following the failure of clinical trials.

$\mathrm{AD}$ begins with changes in neuropathology in the hippocampus and as the disease progresses, spread to the cortex. Short term memory loss is one of the earliest signs, followed by long-term memory loss, confusion and mood swings. The later signs include anterograde amnesia, depression, irritability, language problems and memory retrieval deficits in explicit memory. Ultimately, patients are severely demented, lose ambulation and are reduced to a behavioural repertoire consisting of a few basic reflexes [4,5].

One avenue in searching for a cure is the connection between Down syndrome (DS) and AD. All Down syndrome individuals develop the neuropathology of $\mathrm{AD}$ at an early age but not all develop the clinical symptoms [6]; and the factors involved are not known. DS and AD share the same neuropathology. By the age of 40, DS individuals have developed neuropathology akin to AD [7], which includes $\beta$-amyloid $(\mathrm{A} \beta)$ plaques, tau-containing neurofibrillary tangles (NFT) [8], inflammation [9], basal forebrain cholinergic neuron (BFCN) degeneration [10], microglial degeneration [11], oxidative damage [12] and the presence of enlarged early endosomes [13].

Down syndrome is full or partial trisomy of chromosome 21 (Homo sapiens autosome 21 (HSA21)), and is the most common intellectual disability with prevalence of 1 in 700 live births [14]. It was first described by Dr John Langdon Haydon Down in 1862 [15] who had a grandson with DS. In 1959, DS was classified as a chromosomal abnormality by Jerome Lejeune, a French doctor who detected 47 chromosomes instead of the normal 46 chromosomes in each cell [16]. More than $95 \%$ of DS individuals have an extra whole chromosome 21 which is the result of non-disjunction at maternal meiosis [17], and the risk of having a DS child due to this non-disjunction at meiosis rises with the maternal age [18]. Chromosome 21 is the shortest human autosome and contains $1-1.5 \%$ of the human genome [19]. There are a vast number of characteristics associated with the extra dosage of genes in people with DS [20] such as abnormal craniofacial morphogenesis, deficits in learning and memory, degeneration of basal forebrain cholinergic neurons, premature aging, Alzheimer's disease neuropathology, decreased hippocampal and cerebellar volume, slow growth and development, haematological and immunological disorders and male sterility [21].

People with DS have a much lighter brain compared with people in the general population. The adult DS brain typically weighs about $1000 \mathrm{~g}$ verses about $1350 \mathrm{~g}$ in the non-DS population [22]. The DS brain has a smaller cerebellum, hippocampus, and frontal and temporal cortices $[23,24]$. Although at birth, DS individuals have brains with normal anatomy and morphology, during infancy the brain starts to fail normal development [25]. During the first year of life, the dendrites stop growing; as DS individuals age, the length and thickness of dendritic spines are reduced [25]. The neurons show signs of atrophy, and microglia and astrocytes are more prominent, and there is delayed myelination of oligodendrogliocytes [26]. In addition, there is an imbalance of cellular density within the grey matter [27]. In a recently published longitudinal study by Pujol and colleagues (2018), it was shown that the changes in DS brain volume was consistent with well-known anatomical changes in Alzheimer's disease including the cortical thinning at the early stages [28] and during clinical progression [29] of Alzheimer's disease. Pujol, et al. [30] also stated that their results exhibited DS hippocampal volume degeneration similar to the $\mathrm{AD}$ brain.

It has been suggested that endosomal defects in the brains of both DS and AD may contribute to pathological processes. Furthermore,

${ }^{\star}$ Correspondence to: Nakisa Malakooti, Department of Biochemistry and Molecular Biology, Monash University, Clayton, Victoria, Australia, E-mail: nakisa.malakooti@monash.edu

Key words: down syndrome, alzheimer's disease, amyloid precursor protein, oxidative stress, endosomes

Received: August 15, 2018; Accepted: August 30, 2018; Published: September 04,2018 
enlarged early endosomes, the initial neuropathological alteration known in the sporadic $\mathrm{AD}$, were not observed in healthy aging brains [13]. Early endosomes were distinctly enlarged in DS neurons as early as 28 weeks of gestation [13] and in Ts65Dn, a mouse model of DS [31]. Through endocytosis, neurons achieve the rapid vesicle recycling necessary for maintaining neurotransmission, but endocytosis is also the process used by neurons and other cell types to take up macromolecules from the extracellular environment. Indeed, early endosomes are the sites of internalisation of APP and apolipoprotein $\mathrm{E}$, as well as the site of $\mathrm{A} \beta$ peptide generation and is believed that all contribute to the development of the AD [32]. Moreover, defective neuronal growth factor signalling due to disturbances in endocytosis could be an early event in the manifestation of the $\mathrm{AD}$ [33] which can lead to the formation of amyloid plaques, hyperphosphorylated tau and NFTs and BFCN degeneration [34]. As mentioned, in DS, enlarged endosomes are present as early as 28 weeks of pregnancy in neurons [13], which leads to diffuse $A \beta$ plaque deposition apparent at around 12 years of age, and is followed by mature $A \beta$ plaques when the DS individuals are in their 30's [35].

Conti, et al. [36] demonstrated that mitochondrial gene expressions are altered in the DS. Interestingly, both $\mathrm{AD}$ and DS share mitochondrial dysfunction $[37,38]$. It has been shown that mitochondrial dysfunction facilitates or initiates molecular cascades of AD-like pathology [39]. In DS, mitochondrial dysfunction may also contribute to increased levels of oxidative stress leading to $\mathrm{AD}$-neuropathology. Mitochondria are crucial for the regulation of reactive oxygen species (ROS) levels and the production of ATP in neurons [40]. Embryonic DS neurons have reduced levels of mitochondrial activity [38], and DS foetal tissue has decreased mitochondrial DNA (mtDNA) content [41]. Oxidative stress is a well-known cause of the mitochondrial apoptotic pathway [42] and DS foetal neurons display features associated with initiation of the mitochondrial death pathway [43]. Simón et al. [44] using a mouse model of APP overexpression showed that mitochondrial dysfunction is a result of APP overexpression although there was no sign of plaques in their brain. Indeed, Amyloid Precursor Protein (APP) gene that located on chromosome 21 is required for the manifestation of the $\mathrm{AD}$ [45], but not all the DS individual with APP exhibit the clinical symptoms [6]. This evidence demonstrates that there are other genes/factors involved.

Oxidative damage is a common pathway in manifestation of $\mathrm{AD}$ in DS and the general population. It is caused by overexpression of APP [46] and Superoxide dismutase-1 (SOD-1) $[47,48]$ in DS. SOD-1 is also located on chromosome 21 and over-expressed in DS. The SOD-1 overexpression increases the ratio of SOD-1 to catalase and Glutathione Peroxidase (GPx) leading to higher production of hydrogen peroxide $\left(\mathrm{H}_{2} \mathrm{O}_{2}\right)$ and inducing oxidative stress $[47,48]$. Studies have shown that in addition to SOD-1 and APP, other genes located to chromosome 21, such as $S 100 \beta[49,50]$, and Ets-2 [51] contribute to premature neuronal death and the development of AD.

Oxidative damage also includes the damage that the lipid peroxidation by-products such as 4-hydroxy-2-neonal (HNE) induce [52]. HNE, the most toxic by-product of lipid peroxidation, could interact with proteins and modifies them irreversibly impairing their function [53]. It can activate autophagy-lysosomal activity [54] and consequently the caspase-3 and cell death pathway [55]. Telomerase activity which stabilises DNA is downregulated by HNE [56]. It would be of interest to investigate what would trigger oxidative damage in $\mathrm{AD}$ brain of the general population.

Collectively, these are intriguing evidence that indicates looking closer into Down syndrome might have critical answers for Alzheimer's disease not only for Down syndrome but also the general population. The functional genomic study of chromosome 21 and development of the various cellular and mouse models have all offered an astonishing chance to examine the molecular events of genome dose imbalance. Studies of DS could deliver a wealth of knowledge beyond the wellknown features of intellectual disability and dysmorphic characteristics. Understanding the molecular mechanism that leads to the phenotypes of $\mathrm{AD}$ in the $\mathrm{DS}$ could open the doors to limitless therapeutic options and unlock the mystery of Alzheimer's disease.

\section{References}

1. Berchtold NC, Cotman CW (1998) Evolution in the conceptualization of dementia and Alzheimer's disease: Greco-Roman period to the 1960s. Neurobiol Aging 19: 173-189. [Crossref]

2. Alzheimer's disease international, Dementia statistics,AD international. https://www. alz.co.uk/research/statistics [Accessed 12/09/2017]

3. Australian Bureau of Statistics, Cause of death, Australia, http://www.abs.gov.au/ ausstats/abs@.nsf/Lookup/by\%20Subject/3303.0 2015 Main\%20Features Dementia $\sim 10002,26 / 07 / 2017$, Accessed 12/08/2018.

4. McKhann G, Drachman D, Folstein M, Katzman R, Price D, et al. (1984) Clinical diagnosis of Alzheimer's disease: report of the NINCDS-ADRDA Work Group under the auspices of Department of Health and Human Services Task Force on Alzheimer's Disease. Neurology 34: 939-944. [Crossref]

5. McKhann GM, Knopman DS, Chertkow H, Hyman BT, Jack CR, et al. (2011) The diagnosis of dementia due to Alzheimer's disease: Recommendations from the National Institute on Aging-Alzheimer's Association workgroups on diagnostic guidelines for Alzheimer's disease. Alzheimers Dement 7: 263-269. [Crossref]

6. Zigman WB, Schupf N, Sersen E, Silverman W (1996) Prevalence of dementia in adults with and without Down syndrome. Am J Ment Retard 100: 403-412. [Crossref]

7. Ghezzo A, Salvioli S, Solimando MC, Palmieri A, Chiostergi C, et al. (2014) Agerelated changes of adaptive and neuropsychological features in persons with Down Syndrome. PLoS One 9: e113111. [Crossref]

8. Mann DM (1988) The pathological association between Down syndrome and Alzheimer disease. Mech Ageing Dev 43: 99-136. [Crossref]

9. Wilcock DM, Griffin WS (2013) Down's syndrome, neuroinflammation, and Alzheimer neuropathogenesis. J Neuroinflammation 10: 84. [Crossref]

10. Mann DM, Yates PO, Marcyniuk B, Ravindra CR (1987) Loss of neurones from cortical and subcortical areas in Down's syndrome patients at middle age. Quantitative comparisons with younger Down's patients and patients with Alzheimer's disease. $J$ Neurol Sci 80: 79-89. [Crossref]

11. Xue QS, Streit WJ (2011) Microglial pathology in Down syndrome. Acta Neuropathol 122: 455-466. [Crossref]

12. Cenini G, Dowling AL, Beckett TL, Barone E, Mancuso C, et al. (2012) Association between frontal cortex oxidative damage and beta-amyloid as a function of age in Down syndrome. Biochim Biophys Acta 1822: 130-138. [Crossref]

13. Cataldo AM, Peterhoff CM, Troncoso JC, Gomez-Isla T, Hyman BT, et al. (2000) Endocytic pathway abnormalities precede amyloid $\beta$ deposition in sporadic Alzheimer's disease and Down syndrome: differential effects of APOE genotype and presenilin mutations. Am J Pathol 157: 277-286. [Crossref]

14. Epstein CJ (1995) The metabolic and Molecular Bases of Inherited Disease in Down syndrome, McGraw-Hill Inc. 749-794.

15. Down JL (1866) Observations on an ethnic classification of idiots. Ment Retard 33 54-56. [Crossref]

16. Lejeune J, Turpin R, Gautier M (1959) Le mongolisme, premier exemple d'aberration autosomique humaine. Ann Genet 1: 1-49.

17. Hassold T, Sherman S (2000) Down syndrome: genetic recombination and the origin of the extra chromosome 21. Clin Genet 57: 95-100. [Crossref]

18. Sherman SL, Freeman SB, Allen EG, Lamb NE (2005) Risk factors for nondisjunction of trisomy. Cytogenet Genome Res 111: 273-280. [Crossref]

19. Hattori M, Fujiyama A, Taylor TD, Watanabe H, Yada T, et al. (2000) The DNA sequence of human chromosome 21. 405: 311-319. [Crossref] 
20. Pritchard M, Kola I (1999) The "gene dosage effect" hypothesis versus the "amplified developmental instability" hypothesis in Down syndrome, Springer. 299-303.

21. Patterson D, Costa AC (2005) Down syndrome and genetics - a case of linked histories. Nat Rev Genet 6: 137-147. [Crossref]

22. Solitare GB, Lamarche JB (1967) Brain weight in the adult mongol. J Ment Defic Res 11: 79-84. [Crossref]

23. Aylward EH, Li Q, Honeycutt NA, Warren AC, Pulsifer MB, et al. (1999) MRI volumes of the hippocampus and amygdala in adults with Down's syndrome with and without dementia. Am J Psychiatry 156: 564-568. [Crossref]

24. Dierssen M (2012) Down syndrome: the brain in trisomic mode. Nat Rev Neurosci 13 844-858. [Crossref]

25. Takashima S, Iida K, Mito T, Arima M (1994) Dendritic and histochemical development and ageing in patients with Down's syndrome. J Intellect Disabil Res 38: 265-273. [Crossref]

26. Becker L, Mito T, Takashima S, Onodera K (1991) Growth and development of the brain in Down syndrome. Prog Clin Biol Res 373: 133-152. [Crossref]

27. Menghini D, Costanzo F, Vicari S (2011) Relationship between brain and cognitive processes in Down syndrome. Behav Genet 41: 381-393. [Crossref]

28. Dickerson BC, Bakkour A, Salat DH, Feczko E, Pacheco J, et al. (2008) The cortical signature of Alzheimer's disease: regionally specific cortical thinning relates to symptom severity in very mild to mild $\mathrm{AD}$ dementia and is detectable in asymptomatic amyloid-positive individuals. Cereb Cortex 19: 497-510. [Crossref]

29. Sander Verfaillie CJ, Betty Tijms, Adriaan Versteeg, Marije Benedictus R, Femke Bouwman H, et al. (2016) Thinner temporal and parietal cortex is related to incident clinical progression to dementia in patients with subjective cognitive decline. Alzheimers Dement (Amst) 5: 43-52. [Crossref]

30. Pujol J, Fenoll R, Ribas-Vidal N, Martínez-Vilavella G, Blanco-Hinojo L, et al. (2018) A longitudinal study of brain anatomy changes preceding dementia in Down syndrome. Neuroimage Clin 18: 160-166. [Crossref]

31. Cataldo AM, Petanceska S, Peterhoff CM, Terio NB, Epstein CJ, et al. (2003) App gene dosage modulates endosomal abnormalities of Alzheimer's disease in a segmental trisomy 16 mouse model of down syndrome. J Neurosci 23: 6788-6792. [Crossref]

32. Nixon RA (2005) Endosome function and dysfunction in Alzheimer's disease and other neurodegenerative diseases. Neurobiol Aging 26: 373-382. [Crossref]

33. Salehi A, Delcroix JD, Mobley WC (2003) Traffic at the intersection of neurotrophic factor signalling and neurodegeneration. Trends Neurosci 26: 73-80. [Crossref]

34. Capsoni S, Ugolini G, Comparini A, Ruberti F, Berardi N, et al. (2000) Alzheimer-like neurodegeneration in aged antinerve growth factor transgenic mice. Proceedings of the National Academy of Sciences 97: 6826-6831.

35. Lemere C, Blusztajn J, Yamaguchi H, Wisniewski T, Saido T, et al. (1996) Sequence of deposition of heterogeneous amyloid ß-peptides and APO E in Down syndrome: implications for initial events in amyloid plaque formation. Neurobiol Dis 3: 16-32. [Crossref]

36. Conti A, Fabbrini F, D'Agostino P, Negri R, Greco D, et al. (2007) Altered expression of mitochondrial and extracellular matrix genes in the heart of human fetuses with chromosome 21 trisomy. BMC Genomics 8: 268. [Crossref]

37. Shukkur EA, Shimohata A, Akagi T, Yu W, Yamaguchi M, et al. (2006) Mitochondria dysfunction and tau hyperphosphorylation in Ts1Cje, a mouse model for Down syndrome. Hum Mol Genet 15: 2752-2762. [Crossref]

38. Busciglio J, Pelsman A, Wong C, Pigino G, Yuan M, et al. (2002) Altered metabolism of the amyloid $\beta$ precursor protein is associated with mitochondrial dysfunction in Down's syndrome. Neuron 33: 677-688. [Crossref]
39. Tyumentsev MA, Stefanova NA, Muraleva NA, Rumyantseva YV, Kiseleva E, et al. (2018) Mitochondrial Dysfunction as a Predictor and Driver of Alzheimer's DiseaseLike Pathology in OXYS Rats. J Alzheimers Dis 63: 1075-1088. [Crossref]

40. Keating DJ, Dubach D, Zanin MP, Yu Y, Martin K, et al. (2008) DSCR1/RCAN1 regulates vesicle exocytosis and fusion pore kinetics: implications for Down syndrome and Alzheimer's disease. Hum Mol Genet 17, 1020-1030. [Crossref]

41. Baek KH, Zaslavsky A, Lynch RC, Britt C, Okada Y, et al. (2009) Down's syndrome suppression of tumour growth and the role of the calcineurin inhibitor DSCR1. Nature 459: 1126-1130. [Crossref]

42. Lawen A (2003) Apoptosis-an introduction. Bioessays 25: 888-896. [Crossref]

43. Helguera P, Pelsman A, Pigino G, Wolvetang E, Head E, et al. (2005) ets-2 promotes the activation of a mitochondrial death pathway in Down's syndrome neurons. $J$ Neurosci 25: 2295-2303. [Crossref]

44. Simón A-M, Schiapparelli L, Salazar-Colocho P, Cuadrado-Tejedor M, Escribano L, et al. (2009) Overexpression of wild-type human APP in mice causes cognitive deficit and pathological features unrelated to Aß levels. Neurobiol Dis. 33: 369-378. [Crossref]

45. Korbel JO, Tirosh-Wagner T, Urban AE, Chen X-N, Kasowski M, et al. (2009) The genetic architecture of Down syndrome phenotypes revealed by high-resolution analysis of human segmental trisomies. Proc Natl Acad Sci U S A. 106: 12031-12036. [Crossref]

46. Butterfield DA, Swomley AM, Sultana R (2013) Amyloid B-peptide (1-42)-induced oxidative stress in Alzheimer disease: importance in disease pathogenesis and progression. Antioxid Redox Signal 19: 823-835. [Crossref]

47. Muchova J, Sustrova M, Garaiova I, Liptákova A, Blazícek P, et al. (2001) Influence of age on activities of antioxidant enzymes and lipid peroxidation products in erythrocytes and neutrophils of Down syndrome patients. Free Radical Biology and Medicine 31: 499-508.

48. Garaiova I, Muchova J, Sustrova M, Blazicek P, Sivonova M, et al. (2004) The relationship between antioxidant systems and some markers of oxidative stress in persons with Down syndrome. Biologia 59: 787-794.

49. Royston M, McKenzie J, Gentleman S, Sheng J, Mann D, et al. (1999) Overexpression of S100 in Down's syndrome: correlation with patient age and with -amyloid deposition. Neuropathology and applied neurobiology 25: 387-393.

50. Van Eldik LJ, Griffin WS (1994) S100 beta expression in Alzheimer's disease: relation to neuropathology in brain regions. Biochim Biophys Acta 1223: 398-403. [Crossref]

51. Lott IT, Head E, Doran E, Busciglio J (2006) Beta-amyloid, oxidative stress and down syndrome. Curr Alzheimer Res 3: 521-528. [Crossref]

52. Esterbauer H, Eckl P, Ortner A (1990) Possible mutagens derived from lipids and lipid precursors. Mutat Res 238: 223-233. [Crossref]

53. Ayala A, Muńoz MF, Arguelles S (2014) Lipid peroxidation: production, metabolism, and signalling mechanisms of malondialdehyde and 4-hydroxy-2-nonenal. Oxid Med Cell Longev 2014: 360438. [Crossref]

54. Hill BG, Haberzettl P, Ahmed Y, Srivastava S, Bhatnagar A (2008) Unsaturated lipid peroxidation-derived aldehydes activate autophagy in vascular smooth-muscle cells. Biochemical Journal 410: 525-534. [Crossref]

55. Dodson M, Liang Q, Johnson MS, Redmann M, Fineberg N, et al. (2013) Inhibition of glycolysis attenuates 4-hydroxynonenal-dependent autophagy and exacerbates apoptosis in differentiated SH-SY5Y neuroblastoma cells. Autophagy 9: 1996-2008. [Crossref]

56. Pizzimenti S, Briatore F, Laurora S, Toaldo C, Maggio M, et al. (2006) 4-Hydroxynonenal inhibits telomerase activity and hTERT expression in human leukemic cell lines. Free Radical Biology and Medicine 40: 1578-1591.

Copyright: (2018 Malakooti N. This is an open-access article distributed under the terms of the Creative Commons Attribution License, which permits unrestricted use, distribution, and reproduction in any medium, provided the original author and source are credited. 